\title{
ACTIVATING STUDENTS' INTEREST THROUGH WONDERSHARE QUIZ CREATOR SOFTWARE IN READING COMPREHENSION
}

\author{
Ismail Sangkala \\ ismail@unismuh.ac.id \\ Universitas Muhammadiyah Makassar \\ Baso Jabu \\ basojabu@gmail.com \\ Universitas Negeri Makassar \\ A. Muliati \\ amuli@gmail.com \\ Universitas Negeri Makassar
}

\section{ABSTRACT}

This research aimed at finding out whether or not the use of "Wondershare Quiz Creator Software" activates the students' interest in reading comprehension of the English Education Program, Faculty of Teacher Training and Education, Muhammadiyah University of Makassar, Indonesia. In academic Year 2012/2013, based on investigating students' interest in learning of reading comprehension through Wondershare Quiz Creator Software. The research employed the true experimental method. This research assigned two groups namely experimental group and control group. Each group consisted of 45 students. The sample was chosen by applying cluster random sampling technique. The researcher used the questionnaire was given to the students to cover the statements about the students' interest in the implementation of software in reading comprehension. The data obtained through Likert Scale, it was analyzed by using descriptive and inferential statistics through SPSS 16.0 version. In conducting the research, the researcher applied the "Wondershare Quiz Creator Software" and the result showed that there was students' interest at the experimental group after applying the software. It was proven by the result of descriptive and inferential statistics in questioning the students' statements in the posttest. Based on the result of the questionnaire engaged to the experimental group, the interest of the students was dominantly classified as very high interest. There were $12(27 \%)$ of them classified as high interest and 33 students dominated $73 \%$ as very high interest. The students in the experimental group generally agree with the implementation of the software because they had confidence and felt more enthusiastic with the mean score is 86.53 , which was categorized as interesting.

Keywords: Interest, Software, Reading, Experimental, Comprehension, Wondershare. 


\section{INTRODUCTION}

The teacher taught the four skills to the student, but it cannot be using as a measure of student success in mastering English. Based on previous research and experience of teachers, the researcher has seen the ability of the students in every aspect. The skills of students are less prominent. Therefore, the researcher needs to take attention carefully and accurately current issues in study English. It has expected to be a solution to teachers and students in learning English.

The researcher tried to take data from the lecturer was about students' interest for language skills. Based on the interview with them, students' interest for listening skill was interested. Then, speaking skill is very interested, writing skill was average and reading skill was less interest for students. After seeing this data, the researcher had a big reason conducted the research in focusing for reading skill.

The data from above took from some lecturers who had been teaching those classes. It was also had been taken from 2 semesters and it started from the first and the second semester. Then, they jointly concluded that the class was having problems in reading, and problems mostly constrained the understood reading content and students' interest was low. They all realized that the importance of new ways improved the ability of students in reading class to strengthen their comprehension.

So far, most of English Lecturer has used "the traditional ways" in teaching reading. The teachers only gave the students instruction to read books (intensive reading) and then write down the information or to find out the main idea from books. This way give the students feel bored to study. Although, the lecturers had to follow the modern way to teach in this era, the Medias for teaching were blossomed out to follow modern era.

From the statement above, the researcher tried and prepared a new way, which was expecting to improve students' comprehension in reading. As for the preparations was to shift the conventional way towards modern ways or using multimedia technology in teaching and learning processes. This research had been the focus on how technologies were able used as an intervention measure in classes where learners struggled with mother tongue reading comprehension. Mother tongue meant Indonesian capacity in learning to read and we tried to measure the learners' reading comprehension by using program/software. In specific software was evaluating and comparing learners' activation in learning reading comprehension and wanted to see students' interest.

This research was formulated as follows the use of "Wondershare Quiz Creator Software" interest the students in reading at the third-semester of English Education Program at the Muhammadiyah University of Makassar. Based on the problem statements before, the objective of the study is "to find out: students are interested in reading comprehension by using "Wondershare Quiz Creator" 
software.

The finding of the research was expected to provide information about students' interest in learning of reading comprehension through "Wondershare Quiz Creator Software and will function as interest, motivation and encouragement to improve their reading comprehension through "Wondershare Quiz Creator Software.

\section{LITERATURE OF REVIEW}

Mazguru, (2010), stated that an increase in students' motivation and self-reliance is done by using the media-based interactive learning "Wondershare quiz creator software". Media-based interactive learning quiz creator is an interactive learning media about the form or questions presented in the form of a quiz display by using interactive quiz maker application. Quiz interactive allows students to be independent to improve the understanding of the subject matter by pressing the display button on the application.

Hapsari, (2009), stated that interactive learning media could also improve students' independent attitude. Interactive learning media is very easy to use and saves time, but it can educate its students to study independently.

Harmer, (2001:134) said that "As language teachers, we use a variety of teaching aids to explain language meaning and construction, engage students in a topic or as the basis of whole activity." It meant that in a teaching and learning process, especially for language teaching, the existence of media was absolutely needed. By means of media, students got more understanding of the topic taught by their teachers.

Rosch in Suyanto, (2003: 5). Stated that multimedia is a combination of computer and video, multimedia as a combination of three elements, namely sound, images, and text. Multimedia as a tool that can create a dynamic and interactive presentation that combines text, graphics, and animation, audio and video images.

Abdul, G. (2007: 20-22). There were some of the principles that must be considered in the development of instructional media included: principles of readiness and motivation, the use of centering attention, repetition, learners' active participation, and feedback.

\section{METHOD}

Type of the research was quantitative research, so a research method that was more direct to aspects of the calculation of the figures along with the 
analysis of the data was numeric. Furthermore, a quantitative approach was a numerical method of describing observations of material or characteristics (Best, 1981:154). An experimental involves the comparison of the effects of a particular treatment with that of a different treatment or no treatment. In a sample, conventional experiment reference usually made to an experimental group and to a control group (Best, 1981:59).

Then researcher certainly limited the scope from this research, like matter that used in research, population and the sample. It was for more focused on running the research. Such as on, the reading material that was applied "Narrative text". The population that used to conduct the experimental research was the third-grade students of " the Muhammadiyah University of Makassar" Faculty of Teacher Training and Education, English Education Department in the academic year 2013/2014. The total number of the population was 270 students divided into 6 ( six) classes.

The chosen class $3 \mathrm{G}$ and $3 \mathrm{E}$ as a sample in this research by using cluster random sampling, while the number of students in class $3 \mathrm{G}$ was 45 students and class $3 \mathrm{E}$ was 45 students too. So that, the sample was sufficient been enough to represent all the population. The researcher took class $3 \mathrm{G}$ as the experimental group while class $3 \mathrm{E}$ as the control group.

The experimental research there were two variables of primary interest, namely the independent variables and the dependent variable. The dependent variable is the conditions or characteristics that appear, disappear, or change as the experimenter introduces, removes, or changes independent variables (Best, 1981:60).

Based on the definition, the dependent variable was the students' interest in "Wondershare Quiz Creator Software". Independent variable is the conditions or characteristics that the experimenter manipulates in his or her attempt to ascertain their relation to observed phenomena (Best, 1981:60). Based on the definition, the independent variable of this research was the use of Wondershare Share Quiz Creator Program as a medium in teaching reading comprehension.

The researcher used one kind of the instrument; it was a questionnaire. The questionnaire was the students' response toward the use of Wondershare Quiz Creator Software or the experimental group during the reading activity in the treatment. It was delivering after the treatment to support the data that was from the reading test. It consisted of 10 questions, 10 items for positive statements which used Likert Scale consisting of five options: Strongly Agree, Agree, Undecided, Disagree, Strongly Disagree. The data collected through the questionnaire and was used to measure the level of the students' interest in using Wondershare Quiz Creator Software and conducting it at the posttest. 
Table 1. Likert Scale

\begin{tabular}{|c|c|}
\hline Positive Statement & Classification \\
\hline 5 & Strongly agree \\
\hline 4 & Agree \\
\hline 3 & Undecided \\
\hline 2 & Disagree \\
\hline 1 & Strongly disagree \\
\hline
\end{tabular}

(Arikunto, 2006)

Table 2. The rating score of interest classification

\begin{tabular}{|c|c|}
\hline Interval Score & Categor \\
\hline $84-100$ & Strongly Interested (Very \\
\hline $68-83$ & Interested (High) \\
\hline $52-67$ & Moderate \\
\hline $36-51$ & Uninterested (Low) \\
\hline $20-35$ & Strongly Uninterested (Very \\
\hline
\end{tabular}

(Sudjana, 2005)

\section{RESULT AND DISCUSSIONS}

The finding that the researcher reported in this part was based on the analysis of data collection and the application of the technique elaborated in the previous parts.

The scoring of the questionnaires was analyzed statistically based on the application of Likert Scale. The result shows the students interested in learning Reading by using "Wondershare Quiz Creator Software". This is indicated by the percentage of the students' questionnaire shown in the following table:

Table 3. The Percentage of Students' Interest

\begin{tabular}{|l|l|l|l|l|}
\hline No. & Classification & Range & Frequency & Percentage \\
\hline 1. & Very High Interest & $85-100$ & 33 & $73 \%$ \\
\hline 2. & High Interest & $69-84$ & 12 & $27 \%$ \\
\hline 3. & Moderate & $51-68$ & 0 & $0 \%$ \\
\hline 4. & Low Interest & $36-50$ & 0 & $0 \%$ \\
\hline 5. & Very Low Interest & $20-35$ & 0 & $0 \%$ \\
\hline Total & & 45 & 100 \\
\hline
\end{tabular}

(Data from SPSS Version $16,2015)$ 
Based on the classification above, it indicated that the overall responses were only in high interest and very high-interest classification. From 45 students, 33 $(73.00 \%)$ of them reached the high classification, very high interest. The rest 12 $(27.00 \%)$ students have categorized as high-interest classification. From all classifications, none of the students were categorized as moderate, low interest and very low interest. From the data, it was found that all of the students had a high interest in learning English by the method.

Table 4. The Mean Score of Students' Interest

Descriptive Statistics for Questionnaire

\begin{tabular}{|c|c|c|c|c|c|c|c|c|}
\hline & $\mathrm{N}$ & Range & $\begin{array}{r}\text { Minim } \\
\mathrm{u} \mathrm{m}\end{array}$ & Maximu & Sum & Mean & $\begin{array}{c}\text { Std. } \\
\text { Deviatio }\end{array}$ & Variance \\
\hline $\begin{array}{l}\text { Questionaire } \\
\text { Valid } \\
\text { N (listwise) }\end{array}$ & $\begin{array}{r}45 \\
45\end{array}$ & 22 & 76 & 98 & 3894 & 86.53 & 3.894 & 15.16 \\
\hline
\end{tabular}

(Data from SPSS Version

$16,2015)$

In relation to the mean score above, the students reached 86.53 , it can be concluded that the students of the experimental group had a high interest in learning reading comprehension by using the software.

The discussion section deals with the interpretation of the questionnaire result at the posttest and description of data gained, that is presented based on the students' interest in the application.

The questionnaire was given to the students to cover the statements about the students' interest in the implementation of the application in reading comprehension. Based on the result of the questionnaire engaged to the experimental group, the interest of the students was dominantly classified as very high interest. There was $12(27 \%)$ of them classified as high interest and 33 students dominated $73 \%$ as very high interest.

From this fact, it points out that the way of English teacher in conducting materials is closely related to the students' interest or response of English teacher. The teacher classroom management brings together experience, ability and feeling as well as the interest toward teaching English as a foreign language.

The result of the questionnaire that was given after the posttest shows that the students had interested in implementing the method. The questionnaire was given after the posttest to the experimental group to know the students' interest in using the method to learn reading comprehension. Based on the analysis of 
questionnaire the researcher concludes that the students are interested in learning about reading through the method.

The students in the experimental group generally agree with the implementation of the method because it can build their confidence and they feel more enthusiastic about learning reading comprehension. It can be seen from the mean score of the questionnaire, it is 86.53 , which is categorized as interesting. No wonder if the result of the posttest was great to support them to enrich their reading ability. It also is very positively supporting the students in their reading ability.

\section{CONCLUSIONS}

The result of the students' interest from the data about the mean score on the questionnaire, the researcher would like to conclude the findings of it and it begins with the result of the questionnaire that was given after the posttest. It shows that the students have interested in using Wondershare Quiz Creator Software, which was implemented by the researcher. It was shown by the overall responses were only high interest and very high-interest classification. None of the students were categorized as moderate, low interest and very low interest.

\section{REFERENCES}

Arikunto, Suharsimi. (2002). Prosedur Penelitian, Suatu Pendekatan Praktek. Yogyakarta. Rineka Cipta.

Best, J.W. (1981). Research in Education, Fourth Edition. New Jersey: Prentice Hall Inc.

Brooks, Alice R. "Developmental Values in Books." In Frances Henne, et al., eds. Youth Communication and Libraries. Chicago, ALA, 1949, pp. 49-50.

Brown, H.D. (2003). Language Assessment Principles and Classroom Practices: Longman, New York.

Brown, et.al. (1977). Audio Visual Instruction: Technology, Media, and Methods. New York: Mc, Graw Hill Book Company.

Carnine, D., Silbert, J., \& Kameenui, E.J. (1990). Direct Instruction Reading. Ohio: Merill Publishing Co.

Cristensen, B. Larry. (2001). Experimental Methodology $8^{\text {th }}$ ed. USA: A Pearson Education Company.

Daniel, S., et.al. (2006). Suicidality, School Dropout and Reading Problems among Adole scents. Journal of Learning Disabilities, 36(6): 507- 514.

Derewianka, B. Exploring How Texts Work. (1990). Sydney: Primary Teaching Association. Exploring Narratives page 34-46

Finocchiaro, Mary, Ph.D., Bonomo, Michael, MS. InEd. (1973). The Foreign Language

Learner: A Guide for Teacher. New York: Regents Publishing Company, Inc.

Gerlach, V.S., Elly, D.P. (1980). Teaching and Media: a Systematic Approach. New Jersey: Prentice Hall. Inc. 
Grondlund, Norman E. (1976). Measurement and Evaluation in Teaching, New York: Macmillan Publishing Co.

Gronlund, Norman.E. (1981). Measurement and Evaluation Teaching. USA: Macmillan Publishing Co., Inc.

Harmer, J. (2001). The Practice of English Language Testing. London: Longman Group Ltd.

Harris, A.J: E.R Sipay. (1980). How to Increase Reading Ability: Guide to Developmental and Remedial Methods. New York: Longman, Inc.

Heaton, B. (1975). Writing English Language Test. England: Longman Group Limited.

Henning, G. (1987). A Guide to Language Testing: Development, Evaluation, Research, Boston: Heinle \& Heinle Publishers.

Hilman, Arthur W.T.R. Blair, W.H Rupley. (1981). Principles and Practices of Teaching Reading. London: Scott, Foresman Publishing Company.

Getzels, 'Jacob W. (1956). "The Nature of Reading Interests: Psychological Aspects." In Helen M. Robinson, ed. Developing Permanent Interest in Reading (Supplementary Educational Monographs, no. 84). Chicago, University of Chicago Press, p. 7.

Grellet, Franchoise. (1981). A Developing Reading Skill. Practical Guide to Reading Comprehension Exercise. Great Britain: Cambridge University Press.

Kemp. J. E. (1985). Planning and Producing Audiovisual Materials. New York: Chandler Publishing Company.

Kerlinger, F. N. (1965). Foundation of Behavioral Research. New York University: Holt, Rinehart Winston.

Kluckhohn, C., et al. "Values and Value-Orientations in the Theory of Action." In Talcott Parsons, and Edward A. Shils, eds. Toward a General Theory of Action. Cambridge, Mass., Harvard University Press, 1954, p. 395.

Lado, Robert, Ph.D. (1976). Language Testing. London: Longman Group Limited

Mikuleckly, B. S. (2004). More Reading Power: Reading for Pleasure, Comprehension, Skills, Thinking Skills, Reading Faster (2 nd edition). New York: Longman.

Ministry of Education. The Learner as a Reader NZ: Learning Media. Some features of narrative texts page $98-106$.

Mouly. (1976). Test for Experiment. New York: Mac Millian, Inc.

Nuttal, C. (1988). Teaching Reading Skills in a Foreign Language (Practical Language Teaching: No 9) Oxford: Heinemann.

Robinson, Helen M. "Significant Unsolved Problems in Reading," Journal of Reading, 14:77-82+, Nov. 1970.

Simanjuntak, E., G. (1988). Developing Reading Skills for EFL Students. Jakarta: Depdikbud.

Wright, Andrew. (1976). Visual Materials for the Language Teacher: London. Longman group Ltd. 